\title{
вмJ Global Health A bibliometric analysis of COVID-19 research in Africa
}

To cite: Guleid FH, Oyando R, Kabia $\mathrm{E}$, et al. A bibliometric analysis of COVID-19 research in Africa. BMJ Global Health 2021;6:e005690. doi:10.1136/ bmjgh-2021-005690

Handling editor Seye Abimbola

- Additional supplemental material is published online only. To view, please visit the journal online (http://dx.doi.org/10. 1136/bmjgh-2021-005690).

Received 17 March 2021 Revised 19 April 2021

Accepted 20 April 2021

\section{Check for updates}

(c) Author(s) (or their employer(s)) 2021. Re-use permitted under CC BY. Published by BMJ.

${ }^{1}$ Policy Engagement \& Knowledge Translation Unit, KEMRI-Wellcome Trust Research Programme, Nairobi, Kenya ${ }^{2}$ Health Economics Research Unit, KEMRI-Wellcome Trust Research Programme, Nairobi, Kenya

${ }^{3}$ Health Services Unit, KEMRIWellcome Trust Research Programme, Nairobi, Kenya ${ }^{4}$ Center for Tropical Medicine and Global Health, Nuffield Department of Medicine, University of Oxford, Oxford, UK

Correspondence to

Prof. Edwine Barasa;

EBarasa@kemri-wellcome.org

\section{ABSTRACT}

Background The COVID-19 pandemic has led to an unprecedented global research effort to build a body of knowledge that can inform mitigation strategies. We carried out a bibliometric analysis to describe the COVID-19 research output in Africa in terms of setting, study design, research themes and author affiliation. Methods We searched for articles published between 1 December 2019 and 3 January 2021 from various databases including PubMed, African Journals Online, medRxiv, Collabovid, the WHO global research database and Google. All article types and study design were included.

Results A total of 1296 articles were retrieved. $46.6 \%$ were primary research articles, $48.6 \%$ were editorial-type articles while $4.6 \%$ were secondary research articles. $20.3 \%$ articles used the entire continent of Africa as their study setting while South Africa (15.4\%) was the most common country-focused setting. The most common research topics include 'country preparedness and response' (24.9\%) and 'the direct and indirect health impacts of the pandemic' $(21.6 \%)$. However, only $1.0 \%$ of articles focus on therapeutics and vaccines. $90.3 \%$ of the articles had at least one African researcher as author $78.5 \%$ had an African researcher as first author, while $63.5 \%$ had an African researcher as last author. The University of Cape Town leads with the greatest number of first and last authors. $13 \%$ of the articles were published in medRxiv and of the studies that declared funding, the Wellcome Trust was the top funding body.

Conclusions This study highlights Africa's COVID-19 research and the continent's existing capacity to carry out research that addresses local problems. However, more studies focused on vaccines and therapeutics are needed to inform local development. In addition, the uneven distribution of research productivity among African countries emphasises the need for increased investment where needed.

\section{INTRODUCTION}

Since its emergence in China in late 2019, ${ }^{1}$ SARS-CoV-2, the virus that causes COVID19 , has infected over 83 million people and caused over 1.8 million deaths worldwide as of 5 January 2021. ${ }^{2}$ SARS-CoV-2 predominantly infects the airways, and disease can range from asymptomatic and mild respiratory

\section{Key questions}

What is already known?

- Africa's contribution to global health research is low $(1.3 \%)$ considering the high burden of infectious disease on the continent.

What are the new findings?

- Africa is contributing to the generation of COVID-19 knowledge by publishing primary and secondary research articles and editorial and commentary-type articles.

- African authors have made significant contributions to this productivity and are listed as first authors in $78.5 \%$ of the articles and last authors in $63.5 \%$ of the articles.

- South Africa has the highest COVID-19 research productivity among all the African countries.

- How countries prepared and responded was the most recurring research theme while studies on therapeutics and vaccines were under-represented.

What do the new findings imply?

- These findings highlight Africa's capacity to carry out research relevant to its context.

- However, more effort is needed to ensure even distribution of research productivity across the continent.

- More clinical studies on vaccines and therapeutics are needed to provide evidence on efficacy and safety in African populations.

infections to severe acute respiratory distress syndrome, with the latter resulting in organ failure in some individuals and eventually leading to death. ${ }^{3-6}$ In Africa, where the first case was reported in February 2020, there have been 2.8 million cases and over 68000 deaths as of 6 January 2021. ${ }^{7}$ The pandemic, in addition to health system constraints and the burden of existing communicable diseases, has put considerable pressure on already weak health systems across the continent. In addition, measures put in place to control the spread of the virus ${ }^{8}$ have led to the closure of schools, businesses and social services which have generated significant setbacks to Africa's heath programmes, economy and communities. ${ }^{9-14}$ 
As COVID-19 is an emerging infectious disease, the research community has responded rapidly to provide insight into how to control the pandemic and in the development of tests, therapeutics and vaccines. Research on COVID-19 has been predominantly from China, Europe and the USA, ${ }^{15}{ }^{16}$ which is understandable as these regions have experienced more cases and deaths from the pandemic. For reasons that are still uncertain, Africa has experienced fewer cases and deaths in the initial phase of the COVID-19 pandemic compared with other continents. This suggests that local research that considers the local context is necessary to inform contextually relevant mitigation strategies and treatment options.

In this bibliometric analysis, we describe the research on COVID-19 that has been done in Africa in terms of the geographical spread of the research, the study methodologies used, the research trends, funding sources and contributions of authors from Africa to highlight local capacity for research and research areas that are neglected.

\section{METHODS}

\section{Data source}

Published papers and grey literature were searched via a topic search (title/abstract) on the following databases: PubMed, African Journals Online, medRxiv, bioRxiv, Collabovid, the WHO global research database and Google for grey literature. Searches were restricted to those published between 1 December 2019 and 3 January 2021.

\section{Eligibility criteria and study selection}

Only articles with a focus on COVID-19 in Africa were included. Four reviewers independently performed study selection and data extraction. There was no restriction on the type of articles that were included. However, only documents in the English language were considered for the analysis. Differences in opinion were settled by referral to a fifth review author.

\section{Search strategy}

The key search words used were those listed for Africa plus keywords pertaining to COVID-19 or SARS-CoV-2 (full search terms are provided in the online supplemental file). These search words were used in the title/ abstract fields. Retrieved articles were manually checked for validity of search strategy and articles that were outside the scope and any duplicates were removed.

\section{Analysis}

Descriptive analyses were conducted to evaluate the characteristics and types of articles retrieved using Microsoft Excel. These included titles; author information including first author and last author, author countries and affiliations; journal source; funders and funder countries; the research objective; the study setting; and keywords. In order to depict relations among keywords, co-occurrence network analysis was done with VOSviewer

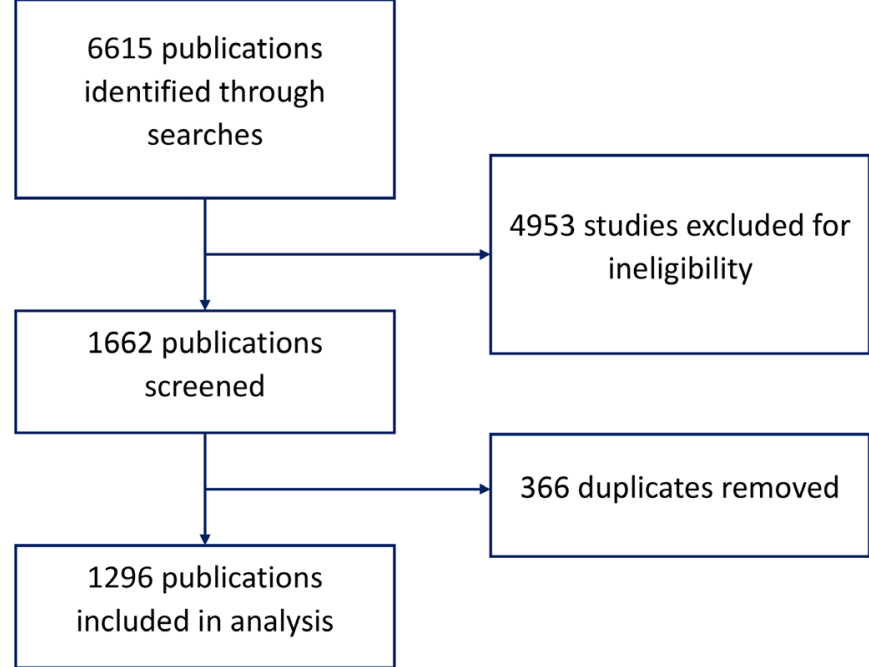

Figure 1 Flowchart for study selection.

(V.1.6.15), a software tool for constructing and visualising bibliometric networks. VOSviewer was also used to assess coauthorship among all the authors in the bibliography and an evaluation of how many of them were connected within documents authored or coauthored by individuals was conducted. The results for the network of actors analysis (supplementary figure 1) and keyword analysis (supplementary figure 2) are included included in the online supplemental file.

\section{Patient and public involvement}

No patients were involved in this study.

\section{RESULTS}

\section{Publication output}

The initial search yielded 6615 articles. After removing duplicates and articles that did not meet the eligibility criteria, we included 1296 articles in our analysis (figure 1).

Of the 1296 articles reviewed, 630 (48.6\%) were non-original research articles (commentary, editorial, perspective pieces, etc), while $606(46.6 \%)$ were primary research articles (research involving the collection and analysis of primary data) and $60(4.6 \%)$ were secondary research articles (research involving the analysis of secondary data). Among the primary research articles, there were 137 modelling studies and 108 survey studies. Of note, we identified five randomised controlled trials (RCT) carried out in Africa. In addition, we identified five systematic reviews including two meta-analyses.

The distribution of countries in which COVID-19 research was conducted is shown in table 1 . Two hundred and sixty-three $(20.3 \%)$ articles used the whole of Africa as their study setting while South Africa $(15.4 \%)$, Nigeria $(12.3 \%)$ and Ethiopia $(6.8 \%)$ were the top three countries with the highest number of country-focused articles (table 1). 
Table 1 Top 10 study settings in which COVID-19 articles were based on in Africa

\begin{tabular}{lllll}
\hline Study setting & $\begin{array}{l}\text { Number of studies } \\
(\mathbf{n = 1 2 9 6 )}\end{array}$ & $\begin{array}{l}\text { Non-original articles } \\
(\mathbf{n = 6 3 0 )}\end{array}$ & $\begin{array}{l}\text { Primary research } \\
(\mathbf{n = 6 0 6})\end{array}$ & $\begin{array}{l}\text { Secondary research } \\
(\mathbf{n}=\mathbf{6 0})\end{array}$ \\
\hline Whole continent (Africa) & 263 & 198 & 41 & 24 \\
\hline South Africa & 200 & 104 & 89 & 7 \\
\hline Nigeria & 160 & 56 & 98 & 6 \\
\hline Ethiopia & 89 & 13 & 75 & 1 \\
\hline Egypt & 70 & 15 & 54 & 1 \\
\hline Kenya & 60 & 22 & 34 & 4 \\
\hline Uganda & 51 & 22 & 29 & 0 \\
Sub-Saharan Africa & 48 & 34 & 12 & 2 \\
\hline Morocco & 46 & 18 & 28 & 0 \\
Ghana & 45 & 20 & 25 & 0 \\
\hline
\end{tabular}

\section{Research themes}

Further, we classified all the articles into specific research groups to determine what the COVID-19 research trends are in Africa and to identify research gaps (table 2). Twenty-five per cent of the articles had a specific focus on assessing countries' preparedness and response to the pandemic while $21.6 \%$ described the indirect health impacts associated with the pandemic.

Of note, only $1 \%$ of the articles focus on therapeutics and vaccines for COVID-19. The least represented research group is virus history and transmission $(0.2 \%)$. These articles focus on the naming of COVID-19 and the implication of naming viruses by location and a review of the history of viral diseases in light of COVID-19.

\begin{tabular}{lc}
\hline $\begin{array}{l}\text { Table } 2 \text { Overview of the top } 15 \text { topics covered in } \\
\text { COVID-19 research articles in Africa }\end{array}$ \\
\hline Study topic & Studies, $\mathbf{n}$ (\%) \\
\hline $\begin{array}{l}\text { Country preparedness and response } \\
\text { Direct and indirect health impacts of } \\
\text { pandemic }\end{array}$ & $282(24.9)$ \\
\hline $\begin{array}{l}\text { Transmission } \\
\text { Knowledge, attitudes and practice }\end{array}$ & $181(13.9)$ \\
\hline Clinical characteristics & $117(9.0)$ \\
\hline Socioeconomic impacts & $78(6.0)$ \\
\hline Description of pandemic & $73(5.6)$ \\
COVID-19 testing & $47(3.6)$ \\
Genomic sequencing & $30(2.3)$ \\
Role of research & $19(1.5)$ \\
\hline Clinical management & $15(1.2)$ \\
\hline Ethics & $14(1.1)$ \\
\hline Therapeutics and vaccines & $14(1.1)$ \\
\hline Infection prevention and control & $13(1.0)$ \\
\hline Impact of pandemic response & $12(0.9)$ \\
\hline Other & $9(0.7)$ \\
\hline
\end{tabular}

\section{Authors}

A total of 8669 authors were identified. Of this, $78.9 \%$ were affiliated with an African institution. 90.3\% of these articles had at least one author affiliated to an African institution. $78.5 \%$ of all the articles reviewed had a first author affiliated to an African institution, while $63.5 \%$ had a last author affiliated to an African institution (figure 2D). There was an equal proportion of nonoriginal $(47.8 \%)$ and primary research articles $(47.1 \%)$ published by African first authors (figure 2B). This was also the case for articles that listed at least one African author (figure 2A). On the other hand, a slightly higher proportion $(53.5 \%)$ of the articles that listed an African last author were primary research articles (figure 2C).

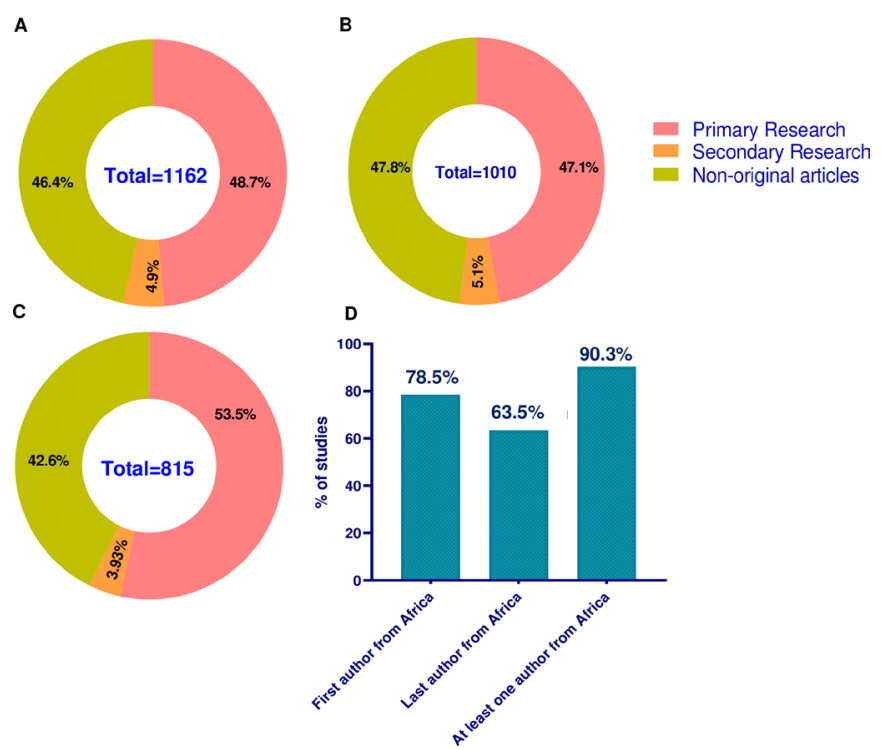

Figure 2 Proportion of articles authored by African researchers and the article type. (A) Proportion of research articles that have at least one African author. (B) Proportion of research articles that have an African first author. (C) Proportion of research articles that have an African last author. (D) Proportion of all articles by author contribution. 
Table 3 Top 15 institutional affiliations of first and last authors of published COVID-19 articles

\begin{tabular}{|c|c|}
\hline University of Cape Town, Cape Town, South Africa & 40 \\
\hline Stellenbosch University, Cape Town, South Africa & 39 \\
\hline University of the Witwatersrand, South Africa & 25 \\
\hline University of KwaZulu-Natal, South Africa & 25 \\
\hline Makerere University, Uganda & 22 \\
\hline University of Pretoria, South Africa & 18 \\
\hline University of Lagos, Nigeria & 14 \\
\hline University of Ibadan, Nigeria & 13 \\
\hline University of Tripoli, Libya & 13 \\
\hline London School of Hygiene \& Tropical Medicine & 12 \\
\hline $\begin{array}{l}\text { KEMRI-Wellcome Trust Research Programme, } \\
\text { Kenya }\end{array}$ & 11 \\
\hline Groote Schuur Hospital, South Africa & 9 \\
\hline University of Zimbabwe, Zimbabwe & 9 \\
\hline $\begin{array}{l}\text { Johns Hopkins Bloomberg School of Public } \\
\text { Health, USA }\end{array}$ & 9 \\
\hline Mohamed V University, Morocco & 8 \\
\hline Institutions & $\begin{array}{l}\text { Last } \\
\text { authors (n) }\end{array}$ \\
\hline University of Cape Town, South Africa & 42 \\
\hline Stellenbosch University, South Africa & 36 \\
\hline University of the Witwatersrand, South Africa & 31 \\
\hline University of KwaZulu-Natal, South Africa & 22 \\
\hline Makerere University, Uganda & 22 \\
\hline University of Pretoria, South Africa & 19 \\
\hline Cairo University, Egypt & 13 \\
\hline University College London, UK & 13 \\
\hline University of Ibadan, Nigeria & 13 \\
\hline $\begin{array}{l}\text { London School of Hygiene \& Tropical Medicine, } \\
\text { UK }\end{array}$ & 13 \\
\hline University of Lagos, Nigeria & 12 \\
\hline University of Oxford, UK & 12 \\
\hline University of Tripoli, Libya & 12 \\
\hline Groote Schuur Hospital, South Africa & 8 \\
\hline $\begin{array}{l}\text { KEMRI-Wellcome Trust Research Programme, } \\
\text { Kenya }\end{array}$ & 7 \\
\hline
\end{tabular}

\section{Author affiliation and network analysis}

The top 15 institutions affiliated with the first and last authors are shown (table 3). Authors from the University of Cape Town (42) and Stellenbosch University (40) published the highest number of articles on COVID-19 in Africa. A network map of coauthors who contributed to COVID-19 research was created at the threshold of three documents per author, resulting in 147 collaborating authors (online supplemental figure 1).
Table 4 Top 15 journals in which COVID-19 research in Africa was published

\begin{tabular}{lc}
\hline Journal & $\begin{array}{l}\text { Studies } \\
\text { (n) }\end{array}$ \\
\hline medRxiv preprint & 174 \\
\hline Pan African Medical Journal & 77 \\
\hline South African Medical Journal & 59 \\
\hline The American Journal of Tropical Medicine and & 31 \\
Hygiene & \\
\hline International Journal of Infectious Diseases & 27 \\
\hline Journal of Global Health & 22 \\
\hline African Journal of Primary Health Care \& Family & 21 \\
Medicine & \\
\hline PLOS One & 18 \\
\hline BMJ Global Health & 15 \\
\hline Lancet Global Health & 12 \\
\hline Clinical Infectious Diseases & 12 \\
\hline BMJ & 11 \\
\hline Lancet & 11 \\
\hline Risk Management and Healthcare Policy & 11 \\
\hline Travel Medicine and Infectious Disease & 11 \\
\hline
\end{tabular}

\section{Journals and funding}

We ranked the top 15 journals that published the highest number of articles. One hundred and seventy-four articles $(13.4 \%)$ had not yet been peer reviewed and were retrieved from the preprint server, medRxiv. Seventyseven articles (5.9\%) were published in the Pan African Medical Journal and 59 (4.5\%) were published in the South African Medical Journal (table 4).

In addition, we ranked the top 15 funding bodies that provided funding for COVID-19 research in Africa (table 5). Of the studies that received funding and included information on the funding source, the Wellcome Trust (23 articles) and the National Institutes of Health (22 articles) were the top two funding bodies.

\section{DISCUSSION}

As the COVID-19 pandemic evolves in Africa and the rest of the world, efforts are being accelerated to identify effective preventive and therapeutic measures to mitigate its burden. Africa has contributed to this research and continues to build a body of evidence that can inform local interventions and mitigation strategies. This bibliometric analysis describes the COVID-19 research that has been carried out in Africa.

The analysis of the study designs published showed that almost half $(48.6 \%)$ of the articles were commentary and editorial pieces and a similar proportion of publications were primary research articles $(46.7 \%)$. Of note, we identified five RCTs carried out in Africa. RCTs are the gold standard for evaluating vaccines and treatment options for COVID-19 and require substantial skills and experiences. While it is encouraging that there are COVID-19 
Table 5 Top 15 funding bodies that provided funding for COVID-19 articles in Africa

\begin{tabular}{lll}
\hline Funding body & $\begin{array}{l}\text { Articles } \\
\text { (n) }\end{array}$ & Country \\
\hline Wellcome Trust & 23 & UK \\
\hline National Institutes of Health & 22 & USA \\
\hline $\begin{array}{l}\text { Bill \& Melinda Gates Foundation } \\
\text { UK Department for International }\end{array}$ & 20 & USA \\
Development & 12 & UK \\
$\begin{array}{l}\text { National Institute for Health } \\
\text { Research }\end{array}$ & 11 & UK \\
\hline $\begin{array}{l}\text { South African Medical Research } \\
\text { Council }\end{array}$ & 10 & South Africa \\
$\begin{array}{l}\text { UK Medical Research Council } \\
\text { European Union }\end{array}$ & 10 & UK \\
\hline $\begin{array}{l}\text { Global Challenges Research Fund } \\
\text { USAID }\end{array}$ & 8 & EU \\
\hline National Research Foundation & 8 & USA \\
\hline $\begin{array}{l}\text { DELTAS } \\
\text { PEPFAR }\end{array}$ & 5 & USA \\
\hline $\begin{array}{l}\text { South African Department of } \\
\text { Science and Innovation }\end{array}$ & 4 & Wellcome Trust and \\
$\begin{array}{l}\text { Canadian Institutes of Health } \\
\text { Research }\end{array}$ & 4 & Canada Initiative \\
\hline & 4 & USA \\
\hline
\end{tabular}

RCTs done in Africa, it is still a small figure compared with the number of other RCTs ongoing in the rest of the world. ${ }^{17}$ This presents a problem as findings from RCTs on different populations may not be generalisable to the African population. In addition, locally conducted RCTs are better placed to consider context-specific issues that would generate more effective interventions. More African countries must carry out or take part in RCTs to generate evidence that represents the African population. Secondary research articles represented only $4.6 \%$ of the included articles. However, this is expected as these types of articles require a large volume of primary research which is currently not available as COVID-19 is still a new research area.

Further, we explored the major themes in COVID-19 research in Africa. Most of the articles (25\%) focused on describing the steps that African countries have taken to prepare and respond to the COVID-19 pandemic. This is expected as all countries took specific measures to prepare and respond to the pandemic. Research detailing these responses and their effects provides insight for further action and can inform future pandemics. Next, $21.6 \%$ of articles focused on the direct and indirect health impacts COVID-19 has had by highlighting the disruption and adaptation of health services catering to people with other diseases such as HIV and malaria. Articles describing transmission and clinical characteristics of the virus were another common field of study. Importantly, therapeutics and vaccine studies were under-represented $(1 \%)$. This raises several concerns as control of COVID-19 will require safe and effective therapeutics and vaccines. First, a lack of local research informing vaccine and therapeutics development leads to an over-reliance on nonAfrican countries to provide these interventions which will delay availability in Africa. Second, Africa requires interventions that fit the local context and is safe for the local population. Therefore, further research on prevention and treatment should be prioritised if we are to mitigate the effects of the pandemic.

Most of the articles included in the analysis focused on the whole continent as the study setting. In the remaining articles, South Africa was the dominant study setting identified. This finding is also in line with other studies that have assessed the volume of all health research from Africa where they report that South Africa has the highest publication output on the continent. ${ }^{18-20}$ This could be explained by several factors. For example, six of the top 15 institutions contributing to COVID-19 body of research in Africa are based in South Africa and increased capacity for research in terms of number of research institutions is important for increasing productivity. Nachega et al found that the number of public health research institutions present in an African country was associated with research productivity; for every additional research programme, public health research productivity increased by $241 \% .{ }^{21}$ Second, in our analysis of institutions that fund COVID-19 research in Africa, we found that three of the top 15 funding bodies were from South Africa, with the other 12 being non-African. Availability of local funding increases publication output and is likely to focus on local issues. Finally, South Africa's high gross domestic product (GDP) could also account for its high research productivity. Uthman et al reported that an independent factor that influenced research capacity was a country's GDP. ${ }^{19}$ The lower number of articles from most African countries may be due to a lack of an enabling environment like that in South Africa. Progress towards controlling COVID-19 in Africa will require countries to sustain COVID-19 research and ensure that knowledge generated is also translated into effective policy. This means that African countries should strengthen local research capacity by increasing investment in research and supporting scientists on the continent.

Analysis on the authors of these articles indicates that $90.3 \%$ of the articles had at least one African author listed. While this proportion is high, it indicates that 125 articles $(9.7 \%)$ in Africa and African countries lack African representation. Most (92) of these articles were editorialtype articles. Editorial-type articles are important as they provide insights into clinical care and health system responses. It was therefore encouraging to find that only a small proportion of these article types $(14.6 \%)$ lacked African representation which is in contrast to previous findings. ${ }^{22}$ Non-Africa-based researchers often conduct research in Africa on behalf of external agencies in collaboration with African researchers. Although this may be important in the transfer of skills to African researchers, it can also lead to inequity in research partnership 
arrangements that put African researchers at a disadvantage. The representation and position of authors on publications can be used as a proxy to measure participation and leadership in research. Of the articles that had an African author, $78.5 \%$ listed an African first author and $63.5 \%$ had an African as last author. Previous studies found that African researchers were under-represented in studies on infectious diseases in Africa ${ }^{23}$; however, we find that in COVID-19 research, a high proportion of articles were by African authors. This could be due to the urgency of COVID-19 as a public health emergency which has led to a greater demand of research within the continent, increased funding, more time to write and publish and increased priority for COVID-19 publications. ${ }^{24}$ However, a limitation of this analysis is the use of institutional affiliation as an indicator of author nationality. This means that an African author based in a non-African institution would be classified as non-African, and a non-African working in an African institution would be classified as African. This misclassification underestimates the contribution of Africa's large scientific diaspora. Additionally, there was disparity in the geographical representation of African first and last authors. The top four author affiliations were all South African institutions, with the University of Cape Town as the leading institution with the highest number of first and last authors. This is an indicator of the small number of research institutions on the continent and the uneven distribution of these institutions.

Over $13 \%$ of articles identified were published in the preprint servers. This is unsurprising as preprint articles represent a significant proportion of COVID-19 literature. ${ }^{25}$ However, for articles that were peer reviewed and published in journals, we found that three African journals featured in the top 15 journals publishing COVID-19 articles in Africa: Pan African Medical Journal, South African Medical Journal and African Journal of Primary Health Care $\mathcal{E}$ Family Medicine. This is promising as availability of local journals where African researchers can publish their work can increase publication output. Most of the research work that is undertaken in Africa is meant for the local audience and addresses local concerns and may not be fairly represented by western publishers. Therefore, it makes sense if such work are published in African journals. However, there is still a long way to go and the development of local journals and publishing houses should be encouraged so as to create a direct avenue for academics and researchers to publish their research findings.

In the articles that declared funding, most funding was obtained from organisations in the UK and USA. External funding has greatly contributed to increasing scientific research capacity on the continent. However, this may hinder development of sustainable African-led knowledge production and may deflect research priorities away from local needs. African organisations in the top 15 list of funding bodies were all from South Africa. Few studies were funded by African organisations, and specifically, African governments. This is similar to other previous studies which also observed few funders from the continent. ${ }^{26}{ }^{27}$ Although increased investment in science by African governments is being made, the continent still falls behind other global regions with African countries spending less than 1\% of GDP (on average) on research and experimental development. ${ }^{28}$

A major limitation of this study is the inclusion of only English articles. This means that we have missed out on a significant proportion of articles from African countries that do not use English as a main language. In addition, we did not critically appraise the studies/articles included in the analysis and therefore cannot assess the quality of research.

\section{CONCLUSION}

The COVID-19 pandemic has highlighted the urgent need for research that informs effective action. Africa has contributed to this body of research despite the usual challenges associated with research and development in low-resource settings. Contrary to other studies on the output of research publication on infectious diseases, we find that African researchers have played a lead role in publishing COVID-19 research from the continent. However, this productivity is uneven across the continent with only a few countries accounting for majority of the publications. This points to the importance of support for research and development by African governments. In addition, more studies focusing on vaccines and therapeutics are needed to inform local development. Nonetheless, the effort to publish research by Africans for Africans is an indicator of the potential the continent has to contribute to global health research.

Twitter Evelyn Kabia @evekagure, Samuel Akech @Sam_Akech and Edwine Barasa @edwinebarasa

Contributors FHG, SA and EB conceived the protocol. FHG, RO, EK and AM participated in the data collection and extraction. FHG performed data analysis. FHG, SA, RO, EK and EB participated in the article writing.

Funding This manuscript is published with the permission of the Director of KEMRI. FHG is funded by a Wellcome Trust Policy Engagement pilot award (215745); additional funds from a Wellcome Trust core grant awarded to the KEMRI-Wellcome Trust Research Programme (092654) supported this work.

Disclaimer The funders had no role in study design, data analysis, decision to publish, drafting or submission of the manuscript. The views expressed in the papers are for the authors and not for the organisations they represent.

\section{Competing interests None declared.}

Patient consent for publication Not required.

Provenance and peer review Not commissioned; externally peer reviewed.

Data availability statement Data are available upon request. All data relevant to the study are included in the article or uploaded as supplemental information.

Supplemental material This content has been supplied by the author(s). It has not been vetted by BMJ Publishing Group Limited (BMJ) and may not have been peer-reviewed. Any opinions or recommendations discussed are solely those of the author(s) and are not endorsed by BMJ. BMJ disclaims all liability and responsibility arising from any reliance placed on the content. Where the content includes any translated material, BMJ does not warrant the accuracy and reliability of the translations (including but not limited to local regulations, clinical guidelines, terminology, drug names and drug dosages), and is not responsible for any error and/or omissions arising from translation and adaptation or otherwise. 
Open access This is an open access article distributed in accordance with the Creative Commons Attribution 4.0 Unported (CC BY 4.0) license, which permits others to copy, redistribute, remix, transform and build upon this work for any purpose, provided the original work is properly cited, a link to the licence is given, and indication of whether changes were made. See: https://creativecommons.org/ licenses/by/4.0/.

ORCID iD

Edwine Barasa http://orcid.org/0000-0001-5793-7177

\section{REFERENCES}

1 Zhu N, Zhang D, Wang W, et al. A novel coronavirus from patients with pneumonia in China, 2019. N Engl J Med 2020;382:727-33.

2 World Health Organization. Weekly epidemiological update - 5 January 2021, 2020. Available: https://www.who.int/publications/m/ item/weekly-epidemiological-update-5-january-2021

3 Guan W-J, Ni Z-Y, Hu Y, et al. Clinical characteristics of coronavirus disease 2019 in China. N Engl J Med 2020;382:1708-20.

4 Huang $\mathrm{C}$, Wang $\mathrm{Y}$, Li X, et al. Clinical features of patients infected with 2019 novel coronavirus in Wuhan, China. Lancet 2020;395:497-506.

5 Adhikari SP, Meng S, Wu Y-J, et al. Epidemiology, causes, clinical manifestation and diagnosis, prevention and control of coronavirus disease (COVID-19) during the early outbreak period: a scoping review. Infect Dis Poverty 2020;9:29.

$6 \mathrm{Hu} \mathrm{Y,} \mathrm{Sun} \mathrm{J,} \mathrm{Dai} \mathrm{Z,} \mathrm{et} \mathrm{al.} \mathrm{Prevalence} \mathrm{and} \mathrm{severity} \mathrm{of} \mathrm{corona} \mathrm{virus}$ disease 2019 (COVID-19): a systematic review and meta-analysis. J Clin Virol 2020;127:104371.

7 Africa CDC. Latest updates on the COVID-19 crisis from Africa CDC, 2020. Available: https://africacdc.org/covid-19/

8 Haider N, Osman AY, Gadzekpo A, et al. Lockdown measures in response to COVID-19 in nine sub-Saharan African countries. BMJ Glob Health 2020;5:e003319.

9 Thurlow J. COVID-19 lockdowns have imposed substantial economic costs on countries in Africa. IFPRI book chapters 2020:23-5.

10 Arndt C, Davies R, Gabriel S, et al. Covid-19 lockdowns, income distribution, and food security: an analysis for South Africa. Glob Food Sec 2020;26:100410.

11 Mbunge E. Effects of COVID-19 in South African health system and society: an explanatory study. Diabetes Metab Syndr 2020;14:1809-14.

12 Amimo F, Lambert B, Magit A. What does the COVID-19 pandemic mean for HIV, tuberculosis, and malaria control? Trop Med Health 2020;48:32.

13 Abiodun Det al. A review into the clinical characteristics of 2019 Ncov and its potential impact on African economy. International Journal of Public Health and Safety 2020.
14 Spaull N, van der Berg S. Counting the cost: COVID-19 school closures in South Africa and its impact on children. South African Journal of Childhood Education 2020;10:13.

15 Zyoud Sa'ed H, Al-Jabi SW. Mapping the situation of research on coronavirus disease-19 (COVID-19): a preliminary bibliometric analysis during the early stage of the outbreak. BMC Infect Dis 2020;20:1-8.

16 Dehghanbanadaki Het al. Bibliometric analysis of global scientific research on coronavirus (COVID-19). Medical Journal of The Islamic Republic of Iran 2020;34:354-62.

17 Nasrallah AA, Farran SH, Nasrallah ZA, et al. A large number of COVID-19 interventional clinical trials were registered soon after the pandemic onset: a descriptive analysis. J Clin Epidemiol 2020;125:170-8.

18 Tijssen R. Africa's contribution to the worldwide research literature: New analytical perspectives, trends, and performance indicators. Scientometrics 2007;71:303-27.

19 Uthman OA, Wiysonge CS, Ota MO, et al. Increasing the value of health research in the WHO African Region beyond 2015--reflecting on the past, celebrating the present and building the future: a bibliometric analysis. BMJ Open 2015;5:e006340.

20 Kana MA, LaPorte R, Jaye A. Africa's contribution to the science of the COVID-19/SARS-CoV-2 pandemic. BMJ Glob Health 2021;6:e004059.

21 Nachega JB, Uthman OA, Ho Y-S, et al. Current status and future prospects of epidemiology and public health training and research in the WHO African region. Int J Epidemiol 2012;41:1829-46.

22 Naidoo AV, Hodkinson P, Lai King L, et al. African authorship on African papers during the COVID-19 pandemic. BMJ Glob Health 2021;6:e004612.

23 Mbaye R, Gebeyehu R, Hossmann S, et al. Who is telling the story? A systematic review of authorship for infectious disease research conducted in Africa, 1980-2016. BMJ Glob Health 2019;4:e001855.

24 Kambhampati SBS, Vaishya R, Vaish A. Unprecedented surge in publications related to COVID-19 in the first three months of pandemic: a bibliometric analytic report. J Clin Orthop Trauma 2020;11:S304.

25 Fraser N, Brierley L, Dey G, et al. The evolving role of preprints in the dissemination of COVID-19 research and their impact on the science communication landscape. PLoS Biol 2021;19:e3000959.

26 Siegfried N, Clarke M, Volmink J. Randomised controlled trials in Africa of HIV and AIDS: descriptive study and spatial distribution. BMJ 2005;331:742.

27 Zani B, Pienaar ED, Oliver J, et al. Randomized controlled trials of HIV/AIDS prevention and treatment in Africa: results from the Cochrane HIV/AIDS specialized register. PLoS One 2011;6:e28759.

28 Simpkin V, Namubiru-Mwaura E, Clarke L, et al. Investing in health R\&D: where we are, what limits us, and how to make progress in Africa. BMJ Glob Health 2019;4:e001047. 